\title{
KAJIAN KARAKTERISTIK IKLIM MIKRO DALAM PEMUKIMAN: SEBUAH PENDEKATAN BERWAWASAN LINGKUNGAN UNTUK PENATAAN LINGKUNGAN BINAAN
}

\author{
M.Ratodi \\ UIN Sunan Ampel Fakultas Psikologi dan Kesehatan \\ Jl. A.Yani No. 117 Surabaya \\ Email : mratodi04@gmail.com
}

\begin{abstract}
Micro-climate assessment in settlements; an environmenta-based approach built environment structuring. Global warming has become an emerging issue in the environmental field study. The urban conditions with all their environment development and layout still consider as majorrootcause for global warming. This literature study aimsed to find explanation for The rapid development of housing and high-rise buildings considered as a factor that responsible for an alternative approach in the effort of built environment restructuring. The results showed that the increasing of 70\% global temperature within 1970 untills 2004 . Moreover, the density of settlement area also believed as an affecting factor for air temperature increasement. In other words, the rapid presence of built environment contributes significantly to micro-climatic conditions. To accommodate the residential rapid development then the micro-climate assessment can be use as an alternative approach in the effort of built environment restructuring which can lead environmental quality improvement especially in settlement areas and to encourage the community involvement in the effort of sustainable development implementation.
\end{abstract}

Keywords: micro-climate, micro-climatic characteristics, built environment, settelements

\begin{abstract}
Abstrak: Kajian karakteristik iklim mikro dalam pemukiman : sebuah pendekatan berwawasan lingkungan untuk penataan lingkungan binaan. Pemanasan global telah menjadi isu yang mencuat dalam aspek kajian lingkungan. Kondisi perkotaan dengan segala pembangunan dan penataannya masih kerap dijadikan salah satu alasan pemicu terjadinya pemasanan global. Studi literatur ini bertujuan untuk menjelaskan alternatif pendekatan dalam usaha penataan lingkungan binaan. Hasil kajian menunjukkan bahwa maraknya pembangunan bangunan hunian dan gedung bertingkat dianggap sebagai faktor yang bertanggungjawab terhadap 70\% peningkatan suhu global selama kurun waktu 1970-2004. Selain itu kepadatan hunian juga dipercaya sebagai faktor yang mempengaruhi peningkatan suhu udara. Dengan kata kehadiran lingkungan binaan yang pesat memberikan sumbangan yang besar terhadap kondisi iklim mikro. Untuk mengakomodir perkembangan hunian yang semakin pesat maka kajian iklim mikro dengan karakteristik menjadi alternatif pendekatan dalam usaha penataan lingkungan binaan yang bermuara pada perbaikan kualitas lingkungan, khususnya pemukiman serta mendukung usaha pembangunan berkelanjutan dengan melibatkan partisipasi masyarakat.
\end{abstract}

Kata kunci : iklim mikro, karakteristik iklim mikro, lingkungan binaan, hunian 


\section{PENDAHULUAN}

Tatanan masyarakat yang
direncanakan dengan baik akan berkontribusi terhadap hubungan sosial yang baik, memperbaiki derajat kesehatan serta pemanfaatn sumber daya yang lebih baik. Pemukiman memainkan peranan kunci perkembangan wajah kota dan perubahan generasi penghuninya ${ }^{(1)}$. Perumahan yang memadai dan terjangkau merupakan indikasi dari stabilitas sosial dan ekonomi suatu masyarakat.

Perencanaan dan perancangan perumahan dapat turut membantu usaha yang berkelanjutan dalam hal pemanfaatan sumber daya serta memenuhi kebutuhan manusia secara komprehensif(2). Sebuah pemukiman yang ideal, semenjak dari proses pembangunannya sampai dengan pemanfataannya haruslah dapat berkontribusi terhadap keberlangsungan lingkungan melalui penghematan energi, efisiensi sumber daya dan meminimalkan produk limbah selama proses hulu ke hilirnya.

Iklim mikro merupakan kondisi tertentu dari iklim makro yang dihasilkan karena kondisi khusus dari sebuah area yang spesifik dan bersifat lokal(1). Iklim mikro dipengaruhi oleh topografi, permukaan tanah, vegetasi serta lingkungan binaan hasil olahan manusia. Pemukiman dengan konsep keberlanjutan dapat menjadi penyeimbang bagi kebutuhan ekonomi, lingkungan dan sosial dari masyarakat. Ke tiga faktor keberlanjutan ini harus ditujukan dalam sebuah proses perencanaan dan perancangan yang bersifat holistik.

\section{BAHAN DAN CARA PENELITIAN}

Tulisan disajikan secara deskriptif. Sumber data berasal dari studi literatur yang diperoleh melalui hasil penelitian Iek Y, Sangkertadi, Moniaga , I.L tahun 2014(3) tentang "Kepadatan Bangunan Dan Karakteristik Iklim Mikro Kecamatan
Wenang Kota Manado" serta referensi lainnya yang berhubungan dengan materi dalam tulisan ini.

\section{PEMBAHASAN}

\section{Mencapai keberlangsungan lingkungan}

Jumlah pemukiman di Indonesia, baik yang bersifat hunian vertikal dan horisontal menunjukkan perkembangan yang pesat dalam kurun waktu 20 tahun terakhir. Dengan kemunculan hunian baru tersebut memiliki dampak yang besar terhadap lingkungan sekitarnya. Untuk menilai sejauh mana hunia-hunian tersebut berdampak kepada keberlangsungan lingkungan, maka pendekatan kajian iklim dapat dijadikan sebagai alternatifnya.

Dengan pendekatan ini, praktisi perancang hunian dapat mempertajam rancangan mereka untuk memaksimalkan keuntungan dari sisi penentuan bentuk, orientasi hunian serta peletakan bangunan yang dengan demikian akan mengoptimalkan peranan pola angin setempat, ventilasi alami pada bangunan, penyebaran polutan, pencahayaan, kenyamanan thermal serta memberikan landasan bagi peningkatan efisiensi energi .

Kajian Iklim Mikro juga akan mampu menyediakan hunian yang ramah lingkungan, alami serta menyehatkan bagi para penghuni maupun masyarakat secara luas. Beberapa faktor yang bisa menjadi parameter dalam kajian iklim mikro diantaranya Pergerakan angin, Penghawaan alami dan penyebaran polutan, Pencahayaan alami dan bayangan serta panas matahari

\section{Pergerakan angin}

Gaya hidup sehat telah menjadi perhatian khusus di masyarakat setelah terjadi beberapa kasus kesehatan seperti SARS di tahun 2003. Angin yang berhembus di lingkungan pemukiman yang berkembang tidak hanya berdampak kepada kondisi kesehatan para penghuni 
tetapi juga menentukan kenyamanan secara thermal bagi perumahan setempat, sirkulasi pejalan kaki , ruang terbuka eksternal dan lingkungan sekitar.

Angin menjadi salah satu pertimbangan penting dalam merancang ruang publik yang mendukung masyarakat untuk bertemu, berkumpul dan berinteraksi secara sosial. Kajian iklim mikro dapat sebagai alat untuk mengoptimalkan perencanaan perumahan, peletakan atau orientasi kawasan, bentuk bangunan dan permebialitas bangunan untuk meningkatkan pemanfaatan angin dilingkungan secara keseluruhan. Menjadi hal yang penting untuk mengidentifikasi karakteristik dari angin yang ada di setiap area lokasi pembangunan hunian(3).

Untuk menentukan informasi valid tentang besaran dan arah angin, maka data dapat diperoleh dari statiun cuaca dari BMKG setempat. Informasi tersebut dapat digunakan untuk mendapatkan gambaran tentang pola pergerakan angin yang menjadi faktor penting dalam microclimate assessment. Bagi area lokasi pembangunan hunian yang jauh dari stasiun cuaca, maka dapat digunakan metode simulasi dengan menggunakan terowongan angin (wind tunnel).

Penilaian pergerakan udara menjadi sebuah indikator yang berhubungan terhadap angin pada sebuah kota dan pola geometrinya serta menilai kemampuan bentuk bangunan untuk mengoptimalkan angin alamiah yang ada. Indikator ini untuk menentukan bagaimana bentuk pergerakan angin dan seberapa nilai minimum kecepatannya, dimana data ini menjadi panduan yang diperlukan dalam merencanakan dan merancang hunian dan tata ruang kota untuk menghasilkan penetrasi angin yang lebih baik ke dalam ruang kota ataupun bangunan sehingga tercipta pergerakan angin yang baik, khususnya bagi para pejalan kaki.

\section{Penghawaan alami dan Penyebaran Polutan}

Hunian dengan tingkat efisiensi energi tinggi dan terencana dengan baik turut mengurangi tingkat konsumsi energi dan berkontribusi kepada kesejahteraan sosial. Dalam aspek ini, kajian iklim mikro digunakan untuk mengoptimalkan konfigurasi blok bangunan, sebagaimana detail layout arsitektural dan bukaan jendela untuk memaksimalkan penghawaan alami dengan sistem silang pada unit hunian maupun area publik ${ }^{(4)}$.

Dengan mensimulasikan pola arah aliran angin dan besarnya pergerakan udara pada unit hunian tipikal yang berada pada zona ketinggian rendah, menengah ataupun tinggi, maka berbagai pilihan optimalisasi disain dapat dikembangkan untuk meningkatkan fungsi penghawaan alami untuk meminimalkan penyebaran polutan yang berasal dari ruang-ruang yang ada dalam unit hunian.

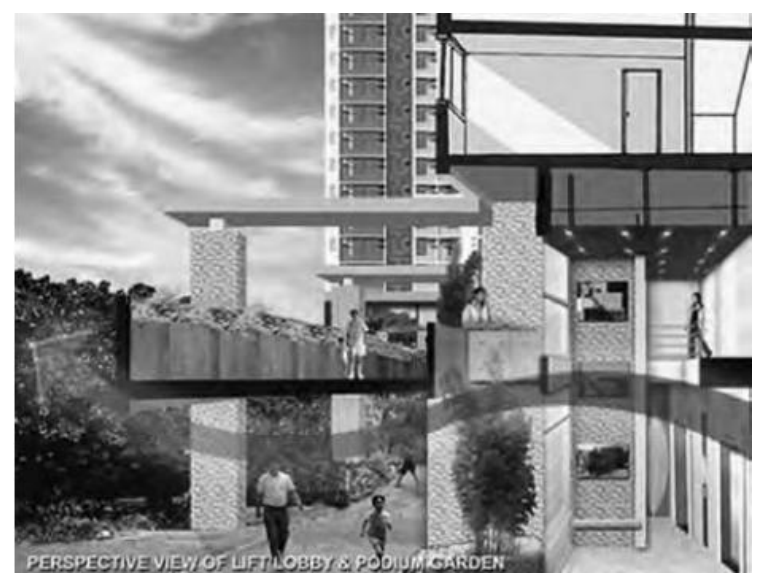

Gambar 1.Taman diatas dek sebagai bentuk pengendalian iklim mikro dan menfasilitasi interaksi sosial pada level dibawahnya(1)

\section{Cahaya alami dan Bayangan}

Cahaya matahari sangat berperang penting bagi kondisi kesejahteraan psikologis dan meningkatkan tingkat kenyamanan pada suatu ruang. Kajian iklim mikro dirancang sebagai alat untuk mengoptimalikan penetrasi cahaya matahari pada unit hunian dan ruang publik 
untuk kepentingan efisiensi energi, kenyamanan dan kesehatan.

Selain itu kajian iklim mikro terkait paparan cahaya alami dilakukan untuk mengoptimalkan perencanaan dan perancangan jenis ruang terbuka pada pembangunan pemukiman, apakah bersifat ruang terbuka yang pasif ataukah aktif. Jumlah cahaya alami pada sebuah permukaan façade bangunan berhubungan dengan tingkat dan intensitas paparan.

Pada pembangunan hunian dengan kepadatan dan perkembangan yang tinggi, sebagian besar penetrasi cahaya melalui bukaan jendela pada lantai bagian bawah dari unit hunian yang berasal dari pantulan cahaya dari permukaan sekitarnya.
Efektifitas bukaan jendela untuk meningkatkan penetrasi cahaya ke dalam area publik dicerminkan oleh penilaian berdasarkan kuantitas cahaya yang dapat masuk. Jendela yang diletakkan bersilangan pada sebuah koridor hunian dapat menekan biaya dalam bentuk penghematan energi sebesar +- 13 persen sekaligus dapat memicu interaksi sosial diantara penghuni yang berada dalam area yang sama

Perhitungan Vertical Daylight Factor (VDF) digunakan sebagai pendekatan berbasis kemampuan sebagai indikator perancangan untuk mengoptimalkan peranan pencahayaan alami.

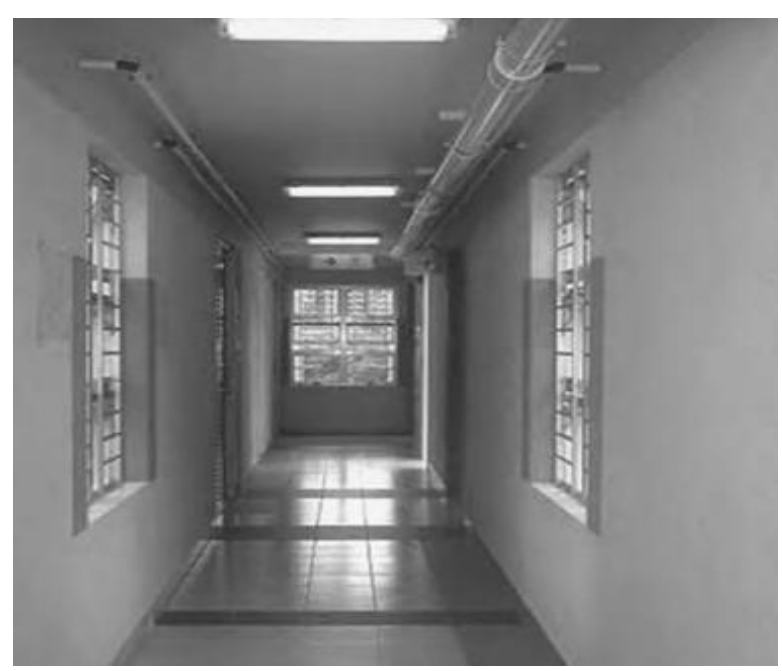

Gambar 2. Peletakan bukaan jendela yang bersilangan memperbaiki daya penetrasi cahaya alami(1)

Bayangan yang dibentuk oleh cahaya matahari juga menjadi salah satu pertimbangan kunci dalam merancang ruang terbuka eksternal yang mampu mendorong orang-orang untuk berkumpul, bertemu secara informil dan berinteraksi sosial. Simulasi jalur siklus pergerakan matahari secara tiga dimensi ditujukan pada daerah setempat untuk mengidentifikasi arah sinar matahari dan pola bayangan di bagian luar hunian pada waktu yang berbeda sepanjang hari dan pada musim yang berbeda pada sepanjang musim(5).

Hal ini merupakan sebuah langkah pendekatan disain terpadu untuk mengoptimalkan paparan sinar matahari pada area hijau, area olahraga pagi, pada area bukaan pada hunian yang difungsikan sebagai area penjemuran pakaian, area yang digunakan untuk aktivitas santai di luar ruangan, bahkan pada area yang digunakan untuk taman bermain anak. Perencanaan 
terhadap ruang terbuka berbasis penataan komprehensif digunakan dalam memaksimalkan peran bayangan matahari(6).

Aktifitas manusia yang diuntungkan dari naungan bayangan yang terbentuk dapat diletakkan sepanjang alur bayangan yang mencukupi. Area yang terkena paparan matahari sepanjang hari dapat diciptakan bayangan dengan menambahkan pepohonan atau naungan. Hal ini ditujukan untuk menciptakan lingkungan yang nyaman untuk berbagai jenis aktifitas luar ruangan.

Dalam beberapa kasus, pengembangan ruang terbuka hijau dilakukan dengan mempertimbangkan faktor tampilan secara fisik dan visual melalui sebuah perencanaan yang detail dan teliti berdasarkan pada hasil simulasi bayangan dan perencanaan lanskap yang peka. Hal ini akan memberikan suasana individu dan identitas tertentu pada setiap hunian atau area.

\section{Panas Matahari}

Sebuah hunian yang nyaman menyediakan landasan bagi kesehatan penghuninya, baik fisik maupun mental. Kajian iklim mikro digunakan sebagai alat perancangan untuk meminimalkan panas matahari yang ditimbulkan dalam sebuah unit hunian dalam rangka mencapai efisiensi energi yang maksimal dan tingkat kenyamanan penghuni yang lebih baik.

Bagian pelapis luar sebuah bangunan merupakan sebuah sistem yang kompleks yang terdiri dari berbagai komponen yang berfungsi bersama-sama untuk menciptakan lingkungan internal yang sehat. Jumlah energi yang mampu dihemat dari usaha menerapkan disain façade yang berkualitas dan biaya yang efektif dalam rangka memperoleh lingkungan dengan ambang batas normal tingkat thermal, dapat dikuantitaskan melalui Nilai Perpindahan Panas/Overall thermal transfer Value
(OTTV) yang terkait dengan panas yang dihasilkan bahan fabrikan, kaca, perancangan jendela dan perangkat penghalang panas( $(6)$.

OTTV selain dapat digunakan sebagai indikator yang efektif dalam kaitannya dengan kenyamanan thermal, OTTV dapat digunakan sebagai referensi yang baik untuk menentukan rencangan warna yang tepat untuk penutup bangunan bagian luar. Fitur façade, yang mempengaruhi beban pendinginan, tingkat jangkauan ventilasi dan penerangan di siang hari, berhubungan dengan konstruksi dinding dan atap, rasio luasan dinding dengan bukaan, jenis kaca, orientasi bangunan, konfigurasi dan pemisahan tingkat lantai, material dan warna yang digunakan sebagai finishing pada bagian eksterior, perangkat penghalang panas(5).

Kajian iklim mikro dapat digunakan untuk merancang perangkat penghalang panas untuk mengurangi efek thermal yang muncul, baik pada bagian penutup bangunan-bangunan publik maupun hunian individu sebagai upaya pengurangan konsumsi energi dari penggunaan Air Conditioner (AC) maupun berbagai penggunaan sistem penghawaan mekanis lainnya.

Dalam rangka mengoptimalkan biaya perawatan, sirip naungan diintegrasikan dalam panel façade pracetak, dengan tentunya tetap mempertimbangkan faktor biaya dalam bongkar muat dan instalasi onsite. Disain lingkungan yang unik akan membawa makna visual bagi hunian dalam kaitannya dengan kondisi iklim mikro di hunian itu sendiri, selain memberikan identitas tersendiri bagi sebuah pemukiman yang mana dapat memunculkan rasa memiliki dan kebersamaan diantara penghuninya sebagai bagian dari masyarakat yang lebih luas. 


\section{KESIMPULAN}

Kawasan pemukiman telah memberikan kontribusi yang substansial terhadap kualitas lingkungan serta kesejahteraan masyarakat. Kajian iklim mikro menjadi instrumen yang bermanfaat dalam memperbaiki kualitas lingkungan terkait perkembangan pemukiman. Kualitas lingkungan dari maraknya perkembagan hunian diharapkan mampu meningkatkan kepedulian publik terkait perkembangan kepadatan lingkungan urban.

Kajian iklim mikro juga dapat menyajikan pendekatan praktis dan perangkat yang objektif dalam memprediksi dampak perkembangan permukiman terhadap kualitas lingkungan pada tahaptahap awal. Kajian ini juga berguna dalam memicu peran serta dan keterlibatan masyarakat, serta memberikan contoh bagaimana permasalahan terkait lingkungan dapat ditangani.

Pemerintah dalam perannya melaksanakan pembangunan berkelanjutan serta medorong keterlibatan masyarakat dalam hal penataan lingkungan, dapat menjadikan kajian iklim mikro sebagai bagian dari usaha implementasi kebijakan berwawasan lingkungan yang efektif.

\section{KEPUSTAKAAN}

1. Ng. Edwar. Designing High-Density Cities For Social \& Environmental Sustainable, UK, Earthscan. 2010

2. Roesmanto, T. Toward Green Architecture and Sustainable City in Nusantara, Simposium International Architecture, Development and Urbanization, Medan, Universitas Tri Karya Medan. 2008

3. Iek Y, , Sangkertadi, Moniaga , I.L, Kepadatan Bangunan Dan Karakteristik Iklim Mikro Kecamatan Wenang Kota Manado, Jurnal Sabua Vol.6, No.3: 285 292 November 2014, Manado, Unsrat. 2014
4. Littlefair, PJ. Environmental Site Layout Planning: Solar Access, Microclimate and Passive Cooling in Urban Areas, London, BRE Ltd. 2000

5. Sangkertadi. Kenyamanan Termis di Ruang Luar Beriklim Tropis Lembab, Bandung, Alfabeta. 2013

6. Purwanto, E. Penggunaan Elemen Kaca pada Bangunan Arsitektur Tropis. Proceeding Seminar Nasional Kaca dalam Arsitektur Bangunan dan Lingkungan, Semarang, Universitas Diponegoro. 2011 